\title{
Status of the Quality of Teaching and Learning Mathematics in Nigerian Colleges of Education
}

\author{
Bessong, Fidelis Ejar \\ Ubana, Ubana Arikpo \\ Udo, David Ekpeyong
}

Doi:10.5901/ajis.2012.v2n5p17

Cross River State College of Education, Akamkpa-Nigeria

Abstract

The standards prescribed by the National Commission for Colleges of Education (NCCE) for teaching and learning Mathematics in Colleges of Education in Nigeria can be said to provide the prescribe condition that Mathematics education should have in the colleges in terms of quality. This study investigated factors limiting the quality of Mathematics Education in selected colleges of education in Nigeria with a view to providing the actual condition of Mathematics education in them. Data on the factors limiting the quality of Mathematics Education was gathered through facebook interview with 109 lecturers teaching Mathematics in the selected colleges. Rating-scale items were also administered to two hundred (200) students from some of the colleges to collect data on the typical learning activities they have experienced during Mathematics lessons. The study discovers that, in respect of facilities and modes of teaching, there are considerable differences between the prescribed condition of Mathematics Education portrayed in the NCCE minimum standards and the actual one depicted by the findings made. The paper recommends provision of adequate resources for Mathematics Education and professional development for Mathematics lecturers, among others.

Key words: Mathematics Education, Quality of Teaching and Learning of Mathematics, Prescribed Condition of Mathematics Education, Actual Condition of Mathematics Education Facilities for Teaching Mathematics, Modes of Teaching Mathematics.

\section{Introduction}

Mathematics education is important for all citizens of a nation because it helps them to be interested in and understand the world around them, be engaged in the discourses of Mathematics, etc. The prescribed condition of Mathematics Education as portrayed in the standards prescribed by the National Commission for Colleges of Education (NCCE) for teaching and learning Mathematics education in colleges of Education in Nigeria needs to be compared with the actual condition on the ground to enable all the stakeholders in this sub-sector of tertiary Education to understand or appreciate the current status of the quality of Mathematics Education in the nation's College of Education. This study was made to find out factors limiting the quality of Mathematics Education as well as the typical learning activities which students have experienced during Mathematics lessons in some selected colleges of Education in Nigeria. This is done with a view to findings out the actual condition of Mathematics education in the colleges in relation with the prescribed condition depicted in the national curriculum provided by the NCCE. However, the scope of the study is confined to facilities and mode of teaching aspects of the ideal picture of Mathematics education contained in the NCCE minimum standard for Mathematics.

\section{Methodology}

A stratified random sampling procedure was used to draw a sampled of 109 lecturers and 200 students. Data on the factors limiting the quality of Mathematics education was gathered through facebook interviews with 109 lecturers teaching Mathematics in the selected colleges. Rating-scale items were also administered to 
two hundred (200) students from the Cross River State College of Education, Akamkpa and the Federal College of Education, Obudu, to collect data on the typical learning activities they have experienced during Mathematics lessons.

Descriptive statistics, namely frequency tables and percentages were used in analyzing the data generated thorough Facebook interviews and the rating-scale items and open-ended questions administered to students.

\section{Factors Leading to Quality Teaching and Learning of Mathematics}

Research shows that all students can learn Mathematics when they have access to high-quality Mathematics teaching and are given sufficient time and support to master a challenging curriculum (Burris, Heubert, \& Levin, 2006; Campbell, 1995; Education Trust, 2005; Griffin, Case, \& Siegler, 1994; Knapp et al., 1995; Silver \& Stein, 1996; Slavin \& Lake, 2008; and Usiskin, 2007, all cited in National Council of Teachers of Mathematics, 2012).

Quality teaching and learning of mathematics has been and will continue to be of major concern to scholars in the field as well as other people whose areas of specialization require some application of mathematics education. This concern is what probably led Sullivan and Mousley, (1994) to conduct a study in which 125 teacher educators and experienced teachers were asked to respond to fixed-format and openresponse items on aspects of mathematics teaching. Based on the findings of the study, the researchers were able to develope a model for quality teaching of mathematics. The model, which has six components, is presented in the diagram below:

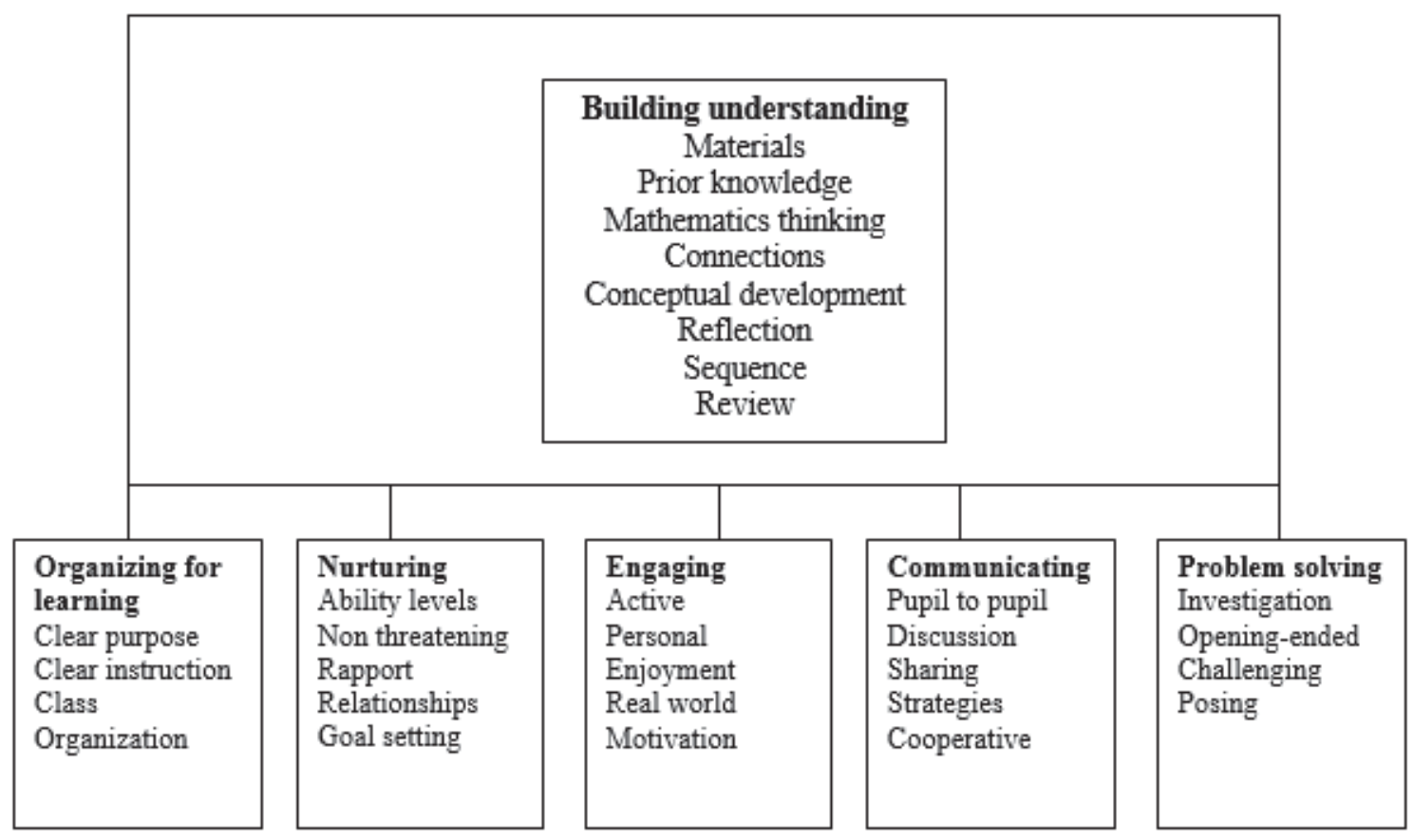

Source: Sullivan and Mousley, (1994) 
It could be seen from the diagram that some relationship exist between the six components of quality teaching of mathematics, for example, Building Understanding, facilitates the other components, namely, organizing for learning, nurturing, engaging, communicating and problem solving.

Looking at the factors which make Singapore to topmost in K-12 Mathematics education, Ahuja (2006) identified the key features contributing to Singapore's success, they include:

a. Students' high educational aspirations and positive attitude towards mathematics,

b. World-class facilities in all schools;

c. Safe school environments;

d. Alternative mathematics framework and special assistance for slow learners;

e. Gifted educational program

f. Excellent textbooks, and

g. Competent and dedicated mathematics teachers.

Another factor is the basic philosophy of streaming reflected in the Singapore Ministry of Education's mission statement:

Every child must be encouraged to progress through the education system as far as his ability allows. Advancement must always depend on performance and merit to ensure equal opportunity for all (MOE, 2003 in Ahuja, 2006).

Furthermore, there are several opportunities in Singapore for students with varying abilities to attend night tuition classes organized by various associations and private companies. As for the mathematics teachers, features contributing to Singapore's success in mathematics education include:

a. a lighter workload for new teachers;

b. the mentoring of new teachers by more experienced teachers;

c. common teacher's rooms with individual desks to work at;

d. well-informed and well-structured guides, worksheets and lesson plans;

e. a lot of cooperation and sharing among teachers within schools, neighbourhoods and at the national level;

f. the availability of manipulative software and computers;

g. most Singapore teachers make an effort to attend meetings, workshops, and conferences during the year; and

h. teachers generally incorporate a variety of methods in teaching mathematics such as assigning theme-based projects and using diagrams and models.

Colleges of education in Nigeria as well as other institutions offering Mathematics can certainly borrow a leaf from the components of the developed model for quality teaching of mathematics and also from the factors leading to high quality mathematics education in Singapore.

\section{The Prescribed condition for Mathematics Education in Nigeria Colleges of Education}

This paper adopts the standards prescribed by the National Commission for Colleges of Education (NCCE) for teaching and learning mathematics education (NCCE, 1997);

1. Philosophies: The philosophy of the Nigeria Certificate in Education (NCE) Mathematics is inspired by the desire to help students become intellectually informed in mathematics ideas, notations and skills for logical reasoning, scientific enquiry and for the pursuit of techno-scientific education. There is a need to produce non-graduates but well-groomed and qualified professional teachers of mathematics for Basic Education levels.

2. Facilities:

(a) classroom; at least three(3) lecture rooms and a lecture theatre 
(b) laboratory: there must be a fully air-conditioned mathematics laboratory with mini micro computers of not more than ten students per one, an overhead projector or multimedia projectors

(c) workshop; there must be a mathematics workshop where students can make their own instructional materials

(d) staff offices: the comfort of teaching staff must be taken into consideration. Ideally, there should be an office per lecturer, equipped with bulletin boards, book shelves, visitors' seat and standard furniture.

(e) The Head of Department should have an office; furnished with accessories. There should also be an office for the supporting staff i.e. typists and clerks

(f) There must be current and relevant textbooks and journals to cover all the areas of the subject

\section{Personnel:}

(a) Academic; A minimum of eight (8) academic staff are specifically required for the NCE mathematics Programme. All the academic staff must have an Educational background with a minimum of second class lower Bachelor of Education degree in Mathematics or Post Graduate Diploma in Education and a second Class Lower (Honours) Degree in Mathematics

(b) Non-Academic; Computer Technical Data Operator

(c) 2 Library Assistant/Attendant, 1 Laboratory Assistant/Attendant, 1 Typist/Secretary, 1 office assistant

4. Mode of teaching: Lecturer, Tutorials, Problem-solving, seminar, Demonstration, Drill, Experimentation, Excursion, Discovery Method, Laboratory Method and etc. Discovery method and laboratory work should be emphasized.

This study was focused at facilities and mode of teaching aspects of the prescribed condition for mathematics education contained in the NCCE minimum standard for Mathematics.

\section{Result of the Study}

This section presents the data obtained from the 109 lecturers and 200 students sampled for the study. This data gives the actual condition under which mathematics education is provided in the selected colleges of education,

The lecturers were asked what factors limited the quality of Mathematics teaching in their schools. Table 1 contains their responses to this question.

Table 1: Factors Limiting the Quality of Teaching and Learning Mathematics

\begin{tabular}{|c|c|c|c|}
\hline$S \backslash$ No & Factor & Sub factor & Frequency \\
\hline \multirow{9}{*}{1} & \multirow{9}{*}{ Resources: } & Inadequate resources & 26 \\
\hline & & Inadequate mathematics budget & 21 \\
\hline & & Poor access to a laboratory for teaching science & 14 \\
\hline & & Inadequate equipment & 13 \\
\hline & & Poor access to computers & 10 \\
\hline & & No access or inadequate access to a laboratory assistant & 2 \\
\hline & & Inadequate Mathematics curriculum resources & 2 \\
\hline & & Computer network is not reliable & 1 \\
\hline & & Inadequate Mathematics software & 1 \\
\hline \multirow[b]{2}{*}{2} & \multirow{2}{*}{$\begin{array}{l}\text { School and } \\
\text { Syllabus } \\
\text { constraints }\end{array}$} & Very large class size & 21 \\
\hline & & $\begin{array}{l}\text { School constraints such as timetabling, interruptions and lack } \\
\text { of support from the school administration or teachers. }\end{array}$ & 12 \\
\hline
\end{tabular}




\begin{tabular}{|c|c|c|c|}
\hline & & $\begin{array}{l}\text { Mathematics teaching is constrained by the NCCE } \\
\text { curriculum. }\end{array}$ & 1 \\
\hline \multirow[b]{2}{*}{3} & \multirow[b]{2}{*}{ Student Factors: } & Poor student behavior, attitude or welfare problems. & 17 \\
\hline & & $\begin{array}{l}\text { Students' inadequate literacy skills or lack of support for } \\
\text { students with learning difficulties. }\end{array}$ & 2 \\
\hline \multirow{6}{*}{4} & \multirow{5}{*}{ Teacher Factors: } & $\begin{array}{l}\text { Teachers have inadequate time for reparation, reflection and } \\
\text { collaboration. }\end{array}$ & 23 \\
\hline & & $\begin{array}{l}\text { Teachers lack the knowledge and skills to teach Mathematics } \\
\text { or lack professional development. }\end{array}$ & 16 \\
\hline & & $\begin{array}{l}\text { There is inadequate time for teaching mathematics and/or } \\
\text { too much content to cover in the available time. }\end{array}$ & 9 \\
\hline & & Insufficient time. & 4 \\
\hline & & $\begin{array}{l}\text { Mathematics teachers have poor attitudes towards teaching } \\
\text { and are unwilling to change. }\end{array}$ & 3 \\
\hline & $\begin{array}{l}\text { Community } \\
\text { support: }\end{array}$ & $\begin{array}{l}\text { Lack of community support for Mathematics teaching and } \\
\text { learning }\end{array}$ & 3 \\
\hline
\end{tabular}

\section{Source: Facebook Survey}

For the resource factor, as indicated in the table, the most frequent factors identified by the lecturers, which limit the teaching of Mathematics in the selected colleges of education are inadequate resources and budget for mathematics education. As for school constraint, while poor attitude and learning behavior are the most frequent student factor inhibiting mathematics education in the Colleges.

Table 2: Report students' responses to items dealing with the typical learning activities that occur in mathematics classrooms

\begin{tabular}{|c|c|c|c|c|c|c|}
\hline $\mathrm{S} / \mathrm{N}$ & \multicolumn{2}{|c|}{$\begin{array}{l}\text { Items dealing with the typical } \\
\text { learning activities }\end{array}$} & Never & $\begin{array}{l}\text { Once a } \\
\text { semester } \\
\text { or less }\end{array}$ & $\begin{array}{c}\text { More than } \\
\text { once a } \\
\text { semester }\end{array}$ & $\begin{array}{l}\text { Nearly } \\
\text { every } \\
\text { lesson }\end{array}$ \\
\hline \multirow[b]{2}{*}{1} & \multirow{2}{*}{$\begin{array}{l}\text { In my } \\
\text { mathematics } \\
\text { class }\end{array}$} & $\begin{array}{l}\text { I watch the teacher } \\
\text { do an experiment }\end{array}$ & $3 \%$ & $3 \%$ & $33 \%$ & $61 \%$ \\
\hline & & $\begin{array}{l}\text { We do experiments } \\
\text { by following } \\
\text { instructions. }\end{array}$ & $24 \%$ & $13 \%$ & $20 \%$ & $43 \%$ \\
\hline 2. & $\begin{array}{l}\text { In Mathematics } \\
\text { we need to be } \\
\text { able to }\end{array}$ & $\begin{array}{l}\text { Think and ask } \\
\text { questions }\end{array}$ & $3 \%$ & $20 \%$ & $37 \%$ & $40 \%$ \\
\hline \multirow{4}{*}{3} & \multirow{4}{*}{$\begin{array}{l}\text { My mathematics } \\
\text { teacher }\end{array}$} & $\begin{array}{l}\text { Tells me how to } \\
\text { improve my work }\end{array}$ & $26 \%$ & $25 \%$ & $39 \%$ & $32 \%$ \\
\hline & & $\begin{array}{l}\text { Gives us quizzes } \\
\text { that we mark to see } \\
\text { how we are going. }\end{array}$ & $23 \%$ & $23 \%$ & $37 \%$ & $17 \%$ \\
\hline & & $\begin{array}{l}\text { Marks our work } \\
\text { and gives it back } \\
\text { quickly. }\end{array}$ & $19 \%$ & $26 \%$ & $20 \%$ & $17 \%$ \\
\hline & & $\begin{array}{l}\text { Makes it clear what } \\
\text { we have to do to } \\
\text { get good marks }\end{array}$ & $10 \%$ & $18 \%$ & $22 \%$ & $26 \%$ \\
\hline
\end{tabular}




\begin{tabular}{|c|c|c|c|c|c|c|}
\hline & & $\begin{array}{l}\text { Uses languages that } \\
\text { is easy to } \\
\text { understand }\end{array}$ & $7 \%$ & $20 \%$ & $31 \%$ & $42 \%$ \\
\hline \multirow{4}{*}{4} & \multirow{4}{*}{$\begin{array}{l}\text { During } \\
\text { Mathematics } \\
\text { class }\end{array}$} & $\begin{array}{l}\text { We have enough } \\
\text { time to think about } \\
\text { what we are doing. }\end{array}$ & $14 \%$ & $31 \%$ & $40 \%$ & $15 \%$ \\
\hline & & $\begin{array}{l}\text { Use computers to } \\
\text { do our science } \\
\text { work. }\end{array}$ & $20 \%$ & $40 \%$ & $31 \%$ & $9 \%$ \\
\hline & & $\begin{array}{l}\text { Look for } \\
\text { information on the } \\
\text { internet at school }\end{array}$ & $16 \%$ & $30 \%$ & $31 \%$ & $23 \%$ \\
\hline & & $\begin{array}{l}\text { I am curious about } \\
\text { the Mathematics } \\
\text { we do. }\end{array}$ & $20 \%$ & $40 \%$ & $35 \%$ & $5 \%$ \\
\hline & & I am bored. & $10 \%$ & $40 \%$ & $32 \%$ & $18 \%$ \\
\hline 5 & $\begin{array}{l}\text { The } \\
\text { Mathematics we } \\
\text { learn at school. }\end{array}$ & $\begin{array}{l}\text { Is relevant to my } \\
\text { future. }\end{array}$ & $12 \%$ & $42 \%$ & $31 \%$ & $15 \%$ \\
\hline
\end{tabular}

As the table shows, $65 \%$ of the students reported that they watched their teachers doing experiments while $43 \%$ carried out experiments by following instructional during almost all lessons. Only $17 \%$ of the students stated that their lecturers marked and returned their work in nearly every lesson. Of the two hundred students, 37\% related that they became bored during lessons more than once in a semester. The table also indicates that only $9 \%$ of the students used computers during the lessons while only $23 \%$ use the internet to source information in nearly every lesson.

The lecturers were also asked to name the most important ways by which the teaching and learning of mathematics could be improved in the colleges. Most of them mentioned more than one approach. The approaches mentioned by the teachers are presented in table 3 .

Table 3: Approaches to improving the quality of Mathematics Teaching

\begin{tabular}{|c|c|c|c|}
\hline$S \backslash N_{0}$ & Factor & Sub factor & Frequency \\
\hline \multirow{3}{*}{1} & \multirow{3}{*}{ Resources: } & Mathematics needs a large budget or more resources & 13 \\
\hline & & Better and more relevant curriculum resources & 8 \\
\hline & & $\begin{array}{l}\text { Better access to computer, softwares, information } \\
\text { technologies }\end{array}$ & 5 \\
\hline \multirow{3}{*}{2.} & \multirow{3}{*}{ Student Factors: } & Students need better attitude to Mathematics. & 2 \\
\hline & & Students need & 1 \\
\hline & & $\begin{array}{l}\text { Students need better literacy standards or more support for } \\
\text { students with learning difficulties. }\end{array}$ & 23 \\
\hline \multirow[t]{2}{*}{3.} & \multirow[t]{2}{*}{ Teacher Factors: } & $\begin{array}{l}\text { Need more time for planning, reflection and collaboration } \\
\text { or reduced teaching loads }\end{array}$ & 22 \\
\hline & & Need for more professional development. & 2 \\
\hline \multirow{4}{*}{4} & \multirow{4}{*}{$\begin{array}{l}\text { Teaching-Learning } \\
\text { Factors: }\end{array}$} & Need smaller classes. & 15 \\
\hline & & The Mathematics program needs more practical work. & 3 \\
\hline & & Need more appropriate assessment e.g. assess less content. & 2 \\
\hline & & Need better student behavior management systems in & 1 \\
\hline
\end{tabular}




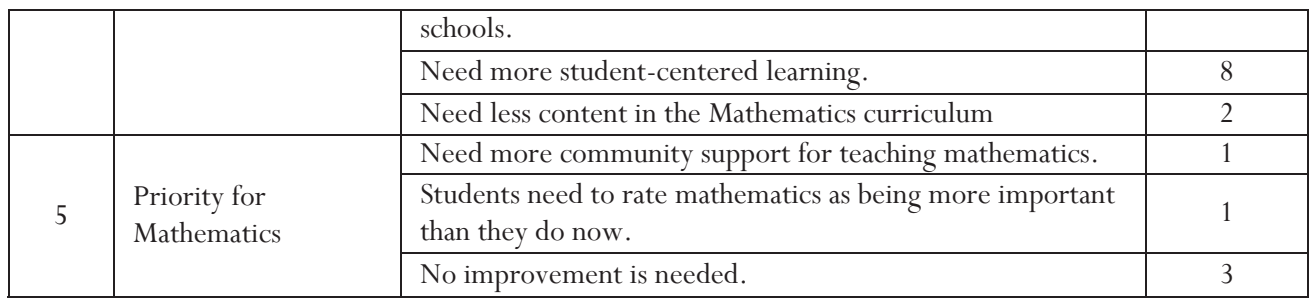

As the table shows, the most frequently mentioned approaches to improving the teaching and learning of Mathematics were more time for planning, reflection, and collaboration with colleagues, mentioned by twenty-two (22) lecturers; professional development, mentioned by twenty-two (22) lecturers; and small class sizes, recommended by fifteen (15) lecturers.

\section{Discussion of Results}

Facilities and mode of teaching are the aspects of the prescribed condition for mathematics education contained in the NCCE minimum standard for Mathematics, which needs to be compared with actual picture shown by the three tables presented above. The ideal in terms of the facilities required for mathematics education include at least three (3) lecture rooms and a lecture theatre, a fully air-conditioned mathematics laboratory with mini micro computers of not more than ten students per one, an overhead projector or multimedia projectors and a mathematics workshop where students can make their own instructional materials also required are an office per lecturer, equipped with bulletin boards, book shelves, visitors' seat and standard furniture, an office for the Head of Department; furnished with accessories and an office for the supporting staff. There must also be current and relevant textbooks and journals to cover all the areas of the subjects to the ratio of one student to ten books. A departmental library is also needed.

When we look at Table 1 which shows the factors limiting the quality of teaching and learning Mathematics in the selected colleges, we see the problems of inadequate resources and budget for Mathematics education. Other problems are large classes, that is, admission of many students which prevents the colleges from having ideal lecturer - students and students - books ratios. The needs for a large budget or more resources for Mathematics education, the needs for smaller classes and better access to computers, software information technologies, which were among the approaches recommended by the lecturer for improving Mathematics education (see table 3) also reflect the problem of shortage facilities needed for quality teaching and learning of Mathematics in the colleges.

On the mode of teaching, the ideal picture speaks of the use of Lectures, Tutorials, problem solving, Seminar, Demonstration, Drill, Experimentation, Excursion, Discovery, Method Laboratory Method, etc. it further stresses that discovery method and laboratory, work should be emphasized. When references is made to Table 2 containing typical learning activities that occur in Mathematics classrooms, it could be seen that $65 \%$ of the students reported that they watched their teachers doing experiments while $43 \%$ carried out experiments by following instructional during almost all lesson. $24 \%$ related that they have never conducted any experiment despite the inclusion of experimentation among the modes of teaching Mathematics. Of the two hundred students included in the study, 37\% related that they became bored during lessons more than once in a semester. This boredom could be as a result of frequent use of lecture method instead of using other methods as well. In fact, the table also indicates that only $9 \%$ of the students used computers during their lessons while only $23 \%$ use the internet to source information in nearly every lesson. The need for smaller classes and better access to computers, which were among the approaches recommended by the lecturers for improving Mathematics education (see Table 3) also indicate that certain methods of teaching and learning Mathematics, such as discovery and laboratory methods could be adopted only if these needs were met. 


\section{Conclusion}

Based on the findings of this study presented in Table 1, 2 and 3 and the discussion on them, it could be concluded that there are considerable differences between the prescribed condition for Mathematics education portrayed in the NCCE minimum standards in respect of facilities and modes of teaching, and the actual condition depicted by the findings of this study.

\section{Recommendations}

In line with the major findings of this study it is recommended that adequate resources for teaching and learning Mathematics education in Nigerian college of Education should be provided through collective efforts of all tiers of government and community members. Secondly professional development for Mathematics lecturers should provided by the colleges and other agencies like the NCCE and the Tertiary Education Tax Fund. Third, more time for planning, reflection, and collaboration with colleagues' especially through workshops as well as the use of small sizes convenient for lecturing should be given consideration. Lastly, incentives should be provided to attract larger numbers of quality lecturers and students to the teaching and learning of Mathematics, and to retain experienced lecturers in the classroom.

\section{References}

Ahuja, O. P. (2006). "World-class High Quality Mathematics Education for all K-12 American Students" The Montana Mathematics Enthusiast, ISSN 1551-3440. Volume No. 2 pp. 223-248. The Montana Council of Teachers of Mathematics. Date of access June 10, 2012.

National Commission for Colleges of Education (1997) “NCCE TESSA \& Minimum Standards Digitization”. Minimum Standards Science \& Mathematics Sector (Abuja: National Commission for Colleges of Education).

National Council of Teachers of Mathematics (2012). Closing the Opportunity Gap in Mathematics Education, a position of the National Council of Teachers of Mathematics, retrieved on June 10, 2012 from http: / / www.nctm.org/about/content.aspx?id=6350.

Sullivan, Peter and Mousley, Judith (1994). Quality Mathematics Teaching: Describing Some Key Components Mathematics Education Research Journal 1994, Vol. 6, No. 1, 4-22 http://www.merga.net.au/documents/MERJ 61 Sullivan\% Mousley.pdf. Date of access June 10, 2012. 